\title{
Rising incidence of unwed mothers in India; associated social parameters \& institutional guidelines for managing them
}

\author{
Rajshree Dayanand Katke*, Mohit R. Saraogi, Priyanka Pagare
}

Department of Obstetrics \& Gynaecology, Cama and Albless Hospital, Sir J.J. Group of Hospitals, Mumbai, MH, India

Received: 29 August 2014

Revised: 8 September 2014

Accepted: 29 September 2014

\section{*Correspondence:}

Dr. Rajshree Dayanand Katke,

E-mail: drrajshrikatke@gmail.com

Copyright: (C) the author(s), publisher and licensee Medip Academy. This is an open-access article distributed under the terms of the Creative Commons Attribution Non-Commercial License, which permits unrestricted non-commercial use, distribution, and reproduction in any medium, provided the original work is properly cited.

\begin{abstract}
Background: Globally the incidence of unwed mothers is rising. While the incidence is higher in western countries, developing countries like India are soon catching up.

Methods: Ours is a retrospective study from January 2009 to December 2013 analyzing 51 cases of unwed mothers for - changing incidence of unwed mothers in India, to look for predisposing social \& family pressures which may have led to the pregnancy, to study neonatal outcomes in such mothers \& to analyze the role of social worker intervention in the management of such pregnancies.

Results: Our study showed a 50\% rise in the incidence of unwed mothers in our institute over the years with a majority $(49 \%)$ of them being teenaged girls. $68 \%$ unwed mothers were uneducated or had only primary education $\&$ $58.9 \%$ unwed mothers had some predisposing factor which might have contributed to the pregnancy. 52\% unwed mothers (who delivered) opted for institutional admission till term and $35.4 \%$ of these underwent a caesarean section at term (higher than institute LSCS rates). $21.5 \%$ unwed mother united with father with social worker intervention.

Conclusions: Social and demographic parameters play a significant role in the incidence of unwed mothers. Several of these parameters are subject to external regulation \& can reduce incidence of unwed mothers. Also the role of a social worker is priceless in management of these patients.
\end{abstract}

Keywords: Unwed mothers, Social parameters

\section{INTRODUCTION}

Unwed mothers remain a challenge in obstetric practice due to a complex interplay of obstetric, medical, social and Psychological complications associated with them. While unwed mothers are a fairly common occurrence in the western countries, they remain a relatively rare entity in India due to the social taboo associated with them. The generic social issue in illegitimacy is that illicit births are regarded as a threat to the family as a social institute. ${ }^{1}$ However in recent years with growing urbanisation in India and with changes in Knowledge, Attitude and Practice (KAP) amidst the youth, this trend is changing. More and more unwed mothers are seen carrying their pregnancy to term instead of aborting \& an increasing number of unwed mothers are seen coming to the antenatal OPD of government hospitals for check-ups.

\section{Aims and objectives}

We at Cama and Albless hospital, Mumbai - undertook a retrospective study from 2009 to 2014 on unwed mothers, with the following objectives -

- To study the changing trends in the incidence of unwed mothers in our institute over the years.

- To study the social and family backgrounds of unwed mothers in a bid to understand any predisposing or precipitating factors which might have led to their pregnancy. 
- To study the neonatal outcome of babies in such mothers

- To study the effect of social worker intervention in such pregnancies with respect to adoption and attempted reconciliation with the father.

- To establish guidelines or protocols to manage unwed mothers in India.

\section{METHODS}

Ours is a retrospective study carried out in Cama and Albless hospital, Mumbai, over a duration of 5 years from January 2009 to December 2013.

A total of 51 cases of unwed mothers were obtained and evaluated from medical and social worker records.

Our institutional guidelines for unwed mothers are as follows.

1. Early antenatal registration and Counseling of the unwed mother in the presence of family members with a positive and reinforcing attitude.

2. Depending on the weeks of gestation, the unwed mother is given a choice to undergo a medical termination of pregnancy on humanitarian grounds (upto 20 weeks of gestation according to the MTP act).

3. Due to the social taboo associated with this subject in India - unwed mothers are given the option of admission in the antenatal ward of the hospital for the entire duration of the pregnancy. Being a government hospital- it is free for the patient and avoids awkward questions from friends and family members.

4. A social worker reference is done at the earliest. The social worker takes a meticulous history from the mother. He counsels the mother, the immediate family and the father (of the unborn baby). Wherever possible the father (of the unborn baby) is encouraged to marry or accept the unwed mother with objective of providing the baby with a stable family.

5. After the history taking, to rule out foul play - an Emergency Police Report (EPR) is done.

6. Pregnant women, carrying on to term - are given the option of raising the women as a single parent with her family support, or the option of giving the baby up for adoption at birth.

7. If the woman opts for adoption, the statement of the woman and her guardian is taken on an affidavit paper for the same. Then after obtaining a no objection from the police \& taking consent from the superintendent, the baby and mother are referred to a recognized adoption agency which does the needful.

8. Wherever depression was suspected, counseling was done by counselors, doctors and staff nurse and if the need arose a psychiatric reference was done.

9. Wherever possible - the patients were delivered at term by a normal vaginal delivery.

10. During antenatal \& post-partum periods, patients are given contraceptive counseling to prevent repeat pregnancies.

The 51 cases of unwed mothers obtained from our records were retrospectively evaluated for

- The incidence of unwed mothers in each years and the changing trend in incidence from 2009 to 2014.

- Associated social \& demographic parameters such as - age, education, occupation, predisposing family problems in household, nature of intercourse which led to pregnancy (forced/consensual), neonatal outcome of baby (given for adoption or raised by mother), and final outcome of mother (married the father or not).

\section{RESULTS}

Total number of antenatal women in our setup from 2009 to 2014 - 9529 (Table 1).

Overall incidence of unwed mothers $-0.53 \%$ (Table 1 ).

Table 1: Incidence of unwed mothers over the years.

\begin{tabular}{|llllll|}
\hline Year & 2009 & 2010 & 2011 & 2012 & 2013 \\
$\begin{array}{l}\text { No. of unwed } \\
\text { mothers }\end{array}$ & 8 & 9 & 7 & 12 & 15 \\
\hline $\begin{array}{l}\text { No. of antenatal } \\
\text { women in our } \\
\text { setup }\end{array}$ & 1882 & 1866 & 1541 & 1961 & 2279 \\
\hline Incidence & $0.42 \%$ & $0.48 \%$ & $0.45 \%$ & $0.61 \%$ & $0.65 \%$ \\
\hline
\end{tabular}

Table 2: Age break up of unwed mothers.

\begin{tabular}{|lllll|}
\hline Age break up & $15-20$ & $21-25$ & $26-30$ & $31-35$ \\
\hline Number of UM & 25 & 22 & 3 & 1 \\
\hline Percentage & $49 \%$ & $43.1 \%$ & $5.8 \%$ & $1.9 \%$ \\
\hline
\end{tabular}

In our retrospective study, data as to the relation of the father to the unwed mother was available only for 42 mothers (Table 6).

In 9 cases the unwed mothers had either refused to talk about the father or the data was not available (Table 6). 
Table 3: Education status of unwed mothers.

\begin{tabular}{|llllll|}
$\begin{array}{l}\text { Education } \\
\text { status }\end{array}$ & $\begin{array}{l}\text { Unedu } \\
\text { cated }\end{array}$ & $\begin{array}{l}\text { Primary } \\
\text { school }\end{array}$ & $\begin{array}{l}\text { Secondary } \\
\text { school }\end{array}$ & College & $\begin{array}{l}\text { Graduation } \\
\text { and post- } \\
\text { graduation }\end{array}$ \\
\hline No. of UM & 16 & 19 & 14 & 2 & 0 \\
\hline Percentage & $31.3 \%$ & $37.2 \%$ & $27.4 \%$ & $3.9 \%$ & $0 \%$ \\
\hline
\end{tabular}

Table 4: Occupation of the mother.

\begin{tabular}{|llllll|} 
Occupation & $\begin{array}{l}\text { Own } \\
\text { business }\end{array}$ & $\begin{array}{l}\text { Maid / } \\
\text { cleaner }\end{array}$ & Student & $\begin{array}{l}\text { Vendor } \\
\text { / shop }\end{array}$ & $\begin{array}{l}\text { Unem } \\
\text { ployed }\end{array}$ \\
\hline No. of UM & 2 & 6 & 11 & 5 & 9 \\
\hline Percentage & $3.9 \%$ & $11.7 \%$ & $21.56 \%$ & $9.8 \%$ & $17.6 \%$ \\
\hline
\end{tabular}

Table 5: Occupation of the mother.

\begin{tabular}{|llllll|} 
Occupation & Beggar & $\begin{array}{l}\text { Commercial } \\
\text { sex worker }\end{array}$ & $\begin{array}{l}\text { Office } \\
\text { Worker }\end{array}$ & $\begin{array}{l}\text { Merchant } \\
\text { (fruit etc.) }\end{array}$ & Others \\
\hline No. of UM & 4 & 1 & 5 & 3 & 5 \\
\hline Percentage & $7.8 \%$ & $1.9 \%$ & $9.8 \%$ & $5.8 \%$ & $9.8 \%$ \\
\hline
\end{tabular}

Table 6: Relation of father to the unwed mother $(n=42)$.

\begin{tabular}{|c|c|c|c|c|c|c|c|}
\hline $\begin{array}{l}\text { Relation } \\
\text { of father }\end{array}$ & Stranger & Neighbour & $\begin{array}{l}\text { Work } \\
\text { colleague }\end{array}$ & $\begin{array}{l}\text { Fellow } \\
\text { student }\end{array}$ & Friend & Relative & Others \\
\hline No. of UM & 5 & 7 & 4 & 6 & 15 & 3 & 2 \\
\hline Percentage & $11.9 \%$ & $16.6 \%$ & $9.5 \%$ & $14.2 \%$ & $35.7 \%$ & $7.1 \%$ & $4.7 \%$ \\
\hline
\end{tabular}

Table 7: Predisposing Factors which may have led to the pregnancy.

\begin{tabular}{|c|c|c|c|c|c|c|c|}
\hline $\begin{array}{l}\text { Predisposing } \\
\text { factors }\end{array}$ & $\begin{array}{l}\text { History of } \\
\text { substance } \\
\text { abuse* }\end{array}$ & $\begin{array}{l}\text { Domestic } \\
\text { violence }\end{array}$ & $\begin{array}{l}\text { Broken } \\
\text { family** }\end{array}$ & Homelessness & Depression & None & $\begin{array}{l}\text { Data not } \\
\text { available }\end{array}$ \\
\hline No. of UM & 5 & 4 & 5 & 3 & 6 & 17 & 11 \\
\hline Percentage & $9.8 \%$ & $7.8 \%$ & $9.8 \%$ & $5.8 \%$ & $11.7 \%$ & $33.3 \%$ & $21.5 \%$ \\
\hline
\end{tabular}

*Substances like alcohol, bidi, cigarettes, drugs

**History of divorce in family, fights between parents of unwed mother, death of first degree relative at young age

Table 8: Mode of delivery.

\begin{tabular}{|lllllll|}
$\begin{array}{l}\text { Mode of } \\
\text { delivery }\end{array}$ & $\begin{array}{l}1^{\text {st }} \\
\text { trimester } \\
\text { MTP }\end{array}$ & $\begin{array}{l}2^{\text {nd }} \\
\text { trimester } \\
\text { MTP }\end{array}$ & PTVD & FTND & LSCS & $\begin{array}{l}\text { Delivered at } \\
\text { another centre / } \\
\text { lost to follow up }\end{array}$ \\
\hline No. of UM & 3 & 6 & 4 & 15 & 11 & 11 \\
\hline Percentage & $5.88 \%$ & $11.7 \%$ & $7.8 \%$ & $29.4 \%$ & $21.5 \% \%$ & $21.56 \%$ \\
\hline
\end{tabular}

Table 9 shows Patient opting for indoor admission till delivery.

Over the last 5 years 31 unwed mothers carried their pregnancy to term and delivered at our centre (Table 9).
Table 9: Patient opting for indoor admission till delivery $(\mathbf{n = 3 1})$.

\begin{tabular}{|lll|}
\hline ANC management & $\begin{array}{l}\text { Indoor admission } \\
\text { to term }\end{array}$ & $\begin{array}{l}\text { OPD follow } \\
\text { up }\end{array}$ \\
\hline No. of unwed mothers & 16 & 15 \\
\hline Percentage & $51.6 \%$ & $48.3 \%$ \\
\hline
\end{tabular}


Table 10: Response of father on social worker intervention.

\begin{tabular}{|lllll|}
$\begin{array}{l}\text { Reaction of } \\
\text { father }\end{array}$ & $\begin{array}{l}\text { Not traceable/ } \\
\text { refused to come }\end{array}$ & $\begin{array}{l}\text { Refused to } \\
\text { accept mother } \\
\text { and baby }\end{array}$ & $\begin{array}{l}\text { Acceptance of } \\
\text { mother with / } \\
\text { without baby }\end{array}$ & unknown \\
\hline Number & 7 & 26 & 11 & 7 \\
\hline Percentage & $13.7 \%$ & $50.9 \%$ & $21.5 \%$ & $13.7 \%$ \\
\hline
\end{tabular}

31 mothers delivered in our centre while 11 mothers delivered elsewhere (Table 11).

Off the 11 mothers who were accepted by the father; 3 underwent a first or second trimester MTP, 2 were lost to follow up just before delivery and 6 cases went home post-delivery with both parents.

Table 11: Babies given for adoption $(n=31)$.

\begin{tabular}{|llll|}
\hline $\begin{array}{l}\text { Outcome of } \\
\text { baby }\end{array}$ & $\begin{array}{l}\text { Given for } \\
\text { adoption }\end{array}$ & $\begin{array}{l}\text { With } \\
\text { mother }\end{array}$ & $\begin{array}{l}\text { With both } \\
\text { parents }\end{array}$ \\
\hline Number & 17 & 8 & 6 \\
\hline Percentage & $54.8 \%$ & $25.8 \%$ & $19.3 \%$ \\
\hline
\end{tabular}

\section{DISCUSSION}

An analysis of our institutional study shows a rising incidence of unwed mothers in our setup over the last 5 years by almost $50 \%$. This could be attributed to an earlier onset of menarche in Indian women (current national average being 13.5 years) as well as an earlier reproductive exposure. ${ }^{2}$ Also with changing attitudes more and more unwed pregnant women prefer to follow up in government and private hospitals as compared to undergoing illegal abortions, thus creating an apparent rise in the incidence.

In our study $49 \%$ of the unwed mothers were teenaged girls. Globally it is estimated that $20 \%$ of all births are teenaged births. ${ }^{3}$ Hence we can reasonably conclude that unwed pregnancies are disproportionately higher in the teenage group as compared to other age groups. This reflects a vulnerability and emotional immaturity in that age group and emphasizes the need for more support during the teenage years for women.

Our study shows that an overwhelming $68 \%$ of unwed mothers were either uneducated or had only primary education. We did not have a single unwed mother who was a graduate or post graduate. Degree of unwed pregnancies in our study was almost inversely proportional to the mothers education. Hence in order to curb the rising incidence of unwed mothers globally, a useful intervention would be to try and acquire universal and higher education for the girl child, especially in developing countries.

$21.56 \%$ of all unwed mothers in our study were students \& $17.6 \%$ were unemployed. The large percentage of students getting pregnant out of wedlock reflects the role of teenage vulnerability, changes in the reproductive system which makes the person susceptible to this problem, and possibly peer pressure in that age group. The high incidence of unwed pregnancies in unemployed women emphasizes the need for social pre-occupation to prevent the occurrence of unwanted pregnancies.

In our study only $11 \%$ women got pregnant from strangers. The large majority were impregnated by acquaintances of which friends occupied the largest group $(35.7 \%)$.

$58.9 \%$ of unwed mothers for whom data was available (39 mothers) had some predisposing history which might have contributed to the pregnancy. Substance abuse and women with broken families seemed to have the highest predisposition.

Tackling these issues can help reduce the incidence of pregnancies out of wedlock. These are factors which need urgent addressing as they can have an impact in the postnatal period as well.

31 unwed mothers delivered in our centre. Of these 10 (35.4\%) underwent a caesarean section (LSCS), a rate which is higher than the overall LSCS rate for our institute. This is because a large number of these were teenage primigravidas, whose pelvis was inadequate for normal vaginal delivery. Most women presented to us late in second trimester and were hence not eligible for MTP. This was because a large majority of them were too afraid to disclose their pregnancy to their family. They were only discovered later in the second trimester due to their enlarging abdominal girth.

$51.6 \%$ of the women who delivered at our centre (16 out of 31) opted for antenatal admission in the ward till delivery. This often involved indoor admission for months. This was to avoid the social stigma associated with illicit pregnancies in our country \& because of the fear of being judged by society. These women are the ones most likely to benefit from counseling and social rehabilitation. Also it emphasizes the magnitude of the social stigma associated with illicit pregnancies in Indian society.

Our study also shows that the role of the social worker in such cases is invaluable. The social worker helped unite $21.5 \%$ of the unwed mothers with the father through 
counseling, thus ensuring a complete family for the newborn child.

They also helped in getting $54.8 \%$ of the babies being born adopted though recognized adoption agencies, thus ensuring a safe environment for the new born child.

\section{CONCLUSION}

The incidence of unwed mothers is on the rise, both in India and globally. This is particularly true in teenage girls having some predisposing factors. The number of cases coming to light may still just reflect the tip of the iceberg due to social reservations associated with the topic. Also the rise in numbers may be an apparent rise as more and more unwed mothers now prefer to get treatment at government hospitals and recognized centres as over getting an illegal abortion. This has helped bring down the maternal mortality rates in India.

Socio economic status, educational attainment, cultural factors \& family factors are all well identified risk factors for teenage pregnancies. ${ }^{4}$ By being aware of the sociodemographic parameters affecting unwed pregnancies, we can help bring down their incidence.

Teenage pregnancies are also often associated with anemia preterm delivery and low birth weight, ${ }^{5}$ which often add onto the morbidities of unwed mothers. These are issues which need to be addressed in the antenatal care of these patients.

Recognizing this, several centers all over the world, have established a community center to provide educational, recreational and social work facilities for pregnant unwed mothers. ${ }^{6}$

Judging by the impact social workers have had in the lives of unwed mothers in our setup, it is our firm belief that all unwed mothers should be managed in a centre where social workers facilities are available. While the setting up of a community centre may not be fisible in many places in India yet... following simple guidelines, as in our setup can help prevent most complications for unwed mothers.

\section{Funding: No funding sources}

Conflict of interest: None declared

Ethical approval: The study was approved by the institutional ethics committee

\section{REFERENCES}

1. Vincent CE. Teen-Age unwed mothers in American society. J Soc Issues. 1966;22:22-33.

2. Bhatia BD, Chandra R. Adolescent mother - an unprepared child. Indian J Matern Child Health. 1993 Jul-Sep;4(3):67-70.

3. WHO. Maternal mortality ratio and rates. In: WHO, eds. A Tabulation of Available Information. 3rd ed. Geneva: World Health Organization; 1991: 1-61.

4. Acharya Dev Raj, Bhattarai Rabi, Poobalan Amudha, Van Teijlingen Edwin R. Factors associated with teenage pregnancy in South Asia: a systematic review. Health Sci J. 2010;4(1):3-14.

5. Acharya D, Bhattarai R, Poobalan A, van Teijlingen E, Chapman G. Factors associated with teenage pregnancy in South Asia. Health Sci J. 2010;4(1):314.

6. Bratati Banerjee, GK Pandey, Debashish Dutt et al. Teenage pregnancy: a socially inflicted health hazard. Indian J Community Med. 2009 Jul;34(3):227-31.

7. Philip M. Sarrel. The university hospital and the teenage unwed mother. Am J Public Health. 1967;57(8):1308-13.

DOI: $10.5455 / 2320-1770 . i j r \operatorname{cog} 20141213$

Cite this article as: Katke RD, Saraogi MR, Pagare P. Rising incidence of unwed mothers in India; associated social parameters \& institutional guidelines for managing them. Int J Reprod Contracept Obstet Gynecol 2014;3:942-6. 